\title{
Introgression and pyramiding into common bean market class fabada of genes conferring resistance to anthracnose and potyvirus
}

\author{
Juan José Ferreira $\cdot$ Ana Campa $\cdot$ Elena Pérez-Vega $\cdot$ \\ Cristina Rodríguez-Suárez $\cdot$ Ramón Giraldez
}

Received: 1 July 2011/ Accepted: 28 October 2011/Published online: 7 December 2011

(C) Springer-Verlag 2011

\begin{abstract}
Anthracnose and bean common mosaic (BCM) are considered major diseases in common bean crop causing severe yield losses worldwide. This work describes the introgression and pyramiding of genes conferring genetic resistance to $\mathrm{BCM}$ and anthracnose local races into line $\mathrm{A} 25$, a bean genotype classified as market class fabada. Resistant plants were selected using resistance tests or combining resistance tests and marker-assisted selection. Lines A252, A321, A493, Sanilac BC6-Are, and BRB130 were used as resistance sources. Resistance genes to anthracnose $\left(\mathrm{Co}^{2}{ }^{C}\right.$, $C o-2^{A 252}$ and $\left.C o-3 / 9\right)$ and/or BCM ( $I$ and $\left.b c-3\right)$ were introgressed in line A25 through six parallel backcrossing programs, and six breeding lines showing a fabada seed phenotype were obtained after six backcross generations: line A1258 from A252; A1231 from A321; A1220 from A493; A1183 and A1878 from Sanilac BC6-Are; and line A2418 from BRB130. Pyramiding of different genes were developed using the pedigree method from a single cross between lines obtained in the introgression step: line A1699 (derived from cross A1258 $\times$ A1220), A2438 (A1220 × A1183), A2806 (A1878 × A2418), and A3308 (A1699 × A2806). A
\end{abstract}

Communicated by R. Varshney.

J. J. Ferreira $(\bowtie) \cdot$ A. Campa · E. Pérez-Vega

Área de Cultivos Hortofrutícolas y Forestales, Servicio Regional de Investigación y Desarrollo Agroalimentario (SERIDA),

33300 Villaviciosa, Asturias, Spain

e-mail: jjferreira@serida.org

C. Rodríguez-Suárez

Instituto de Agricultura Sostenible, CSIC,

Apdo. 4084, 14080 Córdoba, Spain

R. Giraldez

Department of Biología Funcional, University of Oviedo,

33006 Oviedo, Asturias, Spain characterization based on eight morpho-agronomic traits revealed a limited differentiation among the obtained breeding lines and the recurrent line A25. However, using a set of seven molecular markers linked to the loci used in the breeding programs it was possible to differentiate the 11 fabada lines. Considering the genetic control of the resistance in resistant donor lines, the observed segregations in the last backcrossing generation, the reaction against the pathogens, and the expression of the molecular markers it was also possible to infer the genotype conferring resistance in the ten fabada breeding lines obtained. As a result of these breeding programs, genetic resistance to three anthracnose races controlled by genes included in clusters $\mathrm{Co}-2$ and $\mathrm{Co}-3 / 9$, and genetic resistance to $\mathrm{BCM}$ controlled by genotype $I+b c-3$ was combined in the fabada line A3308.

\section{Introduction}

Common bean, Phaseolus vulgaris L., is a very polymorphic species, especially in seed phenotypes. A wide variation for coat colors, color distribution, size and shape of bean seeds have been described; due to this polymorphism, a considerable number of market classes have been reported (Voysest 2000). Market class fabada has white, oblong, and very large seeds (90-100 g/100 seeds) and shows an extreme seed phenotype within the species. Landraces with this seed phenotype were originally found in northern Spain (Puerta Romero 1961). Local accessions of the market class fabada are susceptible to anthracnose (Ferreira et al. 2008) and bean common mosaic (BCM), two bean diseases causing severe yield losses worldwide (Singh and Schwartz 2010).

Bean anthracnose, caused by the fungus Colletotrichum lindemuthianum (Sacc. \& Magnus) Lams.Scrib, can affect 
all aerial plant parts at all stages of development. Characteristic symptoms of the infected tissues are black or dark brown colored lesions which can contain conidia (Schwartz 2005). Infected seeds are often discolored, especially in cultivars with white seed coats. In extreme cases, this disease can cause defoliation, fall of the pods and death of the plant. Interaction between $P$. vulgaris and $C$. lindemuthianum is considered race-specific. Based on the response of a set of 12 bean differential cultivars (PastorCorrales 1991), at least 100 races have been reported (Mahuku and Riascos 2004). In northern Spain, races 3, 6, 19, 38 and 102 have been identified; among them races 6 and 38 are the most common ones and are highly aggressive for the market class fabada (Ferreira et al. 2008). Several genes conferring resistance to anthracnose (designated as $\mathrm{Co}$ - followed by a number or letter) have been reported in common bean, whereas only six loci have been integrated in the genetic map: $\mathrm{Co}-1$ in linkage group (LG) 01, Co- $u$ in LG02, Co-3/9 in LG04, Co-5 in LG07, Co-4 in LG08 and Co-2 in LG11 (Kelly and Vallejos 2004; Campa et al. 2005; Geffroy et al. 2008). Except for co-8, all anthracnose resistance genes are dominant. Different studies revealed that these anthracnose resistance loci are organized as clusters of closely linked race-specific genes located on LG01, LG04, LG07 and LG11 (Geffroy et al. 1999; Rodríguez-Suárez et al. 2007, 2008; Campa et al. 2009, 2010; David et al. 2009).

Bean common mosaic can be caused by two related potyvirus, Bean common mosaic virus (BCMV) and Bean common mosaic necrosis virus (BCMNV). Typical BCM symptoms are light and dark green mosaic with or without malformation of leaves, often causing growth reduction. These potyvirus can be transmitted by the seeds at very high rates depending on the bean genotype. Aphid species also contribute to the potyvirus dissemination among plants (Drijfhout and Morales 2005). Different loci can be involved in the resistance to specific strains of BCMV/BCMNV including a single dominant gene $(I)$, and four recessive genes $\left(b c-u, b c-1^{1} / b c-1^{2}, b c-2^{1} / b c-2^{2}\right.$ and $\left.b c-3\right)$. The $I$ gene has been located in a terminal position of LG02 (Freyre et al. 1998; Pérez-Vega et al. 2010) while the $b c-1$ and $b c-3$ genes were mapped in the LG03 and 06, respectively (Johnson et al. 1997; Miklas et al. 2000). The $I$ gene protects against all BCMV strains, but its presence can cause necrotic reactions on leaves or systemic necrosis in plants infected with BCMNV strains. Several gene combinations can protect against strains of these two potyvirus (Drijfhout 1978; Strausbaugh et al. 2003) although the genotype $I+b c-3$ provides immunity or no symptoms (Kelly 1997).

There are few efficient control measures against pathogens, especially against plant virus diseases (Gómez et al. 2009). The use of resistant cultivars provides the most effective and environmentally friendly control method.
Introgression of only one resistance gene in a cultivar can be problematic because the pathogen can quickly overcome plant resistance. The recommended strategy in these cases is to stack several major resistance genes from different sources simultaneously in a genotype (gene accumulation or pyramiding). However, the handling of several resistance loci and different pathogens, including pathogenic variants complicates pyramiding in conventional breeding programs. Therefore, different resistance tests are necessary for each pathogen or pathogenic variant. In addition, different loci may be involved in the genetic control of a resistant phenotype, and the expression of specific genes can be masked due to epistatic interactions.

Specific molecular markers linked to resistance loci to anthracnose and BCM have been described (Miklas et al. 2006). Indirect selection using molecular markers tightly linked to specific genes (marker-assisted selection or MAS), increases the efficiency of breeding programs (Miklas et al. 2006; Collard and Mackill 2008; Gupta et al. 2010). MAS allows selection of genotypes at seedling stage, minimizing the number or size of resistance tests, identification of resistant genotypes in absence of the pathogen, detection and monitoring of specific resistance genes involved in the resistant reactions and, in some cases, differentiation between homozygous and heterozygous genotypes.

The goal of this work was the introgression and pyramiding of genetic resistance to the potyvirus BCMV/ BCMNV and to local races of $C$. lindemuthianum in the market class fabada using conventional breeding methods, combining resistance tests and marker-assisted selection. The specific objectives were: (i) to introgress different genes conferring resistance to $C$. lindemuthianum races and $\mathrm{BCM}$ in the market class fabada; (ii) to pyramid different genes in order to develop new genotypes with a wide resistance spectra to anthracnose and $\mathrm{BCM}$; (iii) to characterize the obtained lines for their resistance against these pathogens as well as for the main morpho-agronomic traits; and (iv) to differentiate the obtained lines using a minimum set of molecular markers. The developed strategies and the obtained lines may be useful for other breeding programs focused to protect against these pathogens or increase the size of seed.

\section{Materials and methods}

\section{Plant material}

Line A25, proceeding from a selection of the Asturian landrace Andecha, was used as recurrent parent for the introgression of different resistance genes. Line A25 has an indeterminate climbing growth habit, very large seeds 
(100 g/100 seeds) and belongs to the market class fabada. Lines A252 (Carioca $\times$ Guanajuato 31), A321 [BAT561 × (G7474 × Guanajuato31)], A493 (Alubia $\times$ BAT93), Sanilac BC6-Are (Sanilac $\times$ Cornell 49242) and BRB130 [ABA33 $\times($ ABA51 $\times$ Calident 314$)]$ were selected as resistant donor to introgress genetic resistance to anthracnose and BCM into line A25. Lines A252, A321 and A493 have a wide spectrum of resistance to anthracnose including the local races 3, 6, 19, 38 and 102 (Menezes and Dianese 1988; Ferreira et al. 2008). Previous studies revealed that line A252 carries two dominant and independent genes for resistance to race 38, one of them located in cluster Co-3/9, LG04, and the other in cluster Co-2, LG11. The Co-2 cluster of A252 also includes a specific resistance gene against race 31 (Rodríguez-Suárez et al. 2007). Line A493 possesses a single dominant gene for resistance to race 38 mapped in cluster Co-3/9 (Méndez de Vigo et al. 2005). Line A321 carries two independent dominant genes for resistance to race 38 (Ferreira et al. 2008), one of them located in cluster Co-3/9, and the other in cluster Co-2 (Méndez de Vigo et al. 2005). Cultivar Sanilac BC6-Are was derived from a backcrossing program, using cultivar Cornell 49242 as resistant donor, and navy bean Sanilac as recurrent parent (Aylesworth et al. 1983). Sanilac BC6-Are carries the Co-2 locus of Cornell 49242, previously named as Are gene (Mastenbroek 1960). Race 31 overcomes the cultivar Cornell 49242 (Krüger et al. 1977), so the symbols $C o-2^{\mathrm{A} 252}$ and $\mathrm{Co}-2^{c}$ are proposed to differentiate between the Co-2 haplotype of A252 (carrying a resistance gene against race 31 ) and that of Cornell 49242 (lacking the resistance gene against race 31), respectively. Sanilac BC6-Are also carries a dominant gene conferring resistance to BCMV, probably the $I$ gene derived from parent Cornell 49242 (Pérez-Vega et al. 2010). Sanilac BC6-Are did not show symptoms of mosaics or systemic necrosis in the resistance tests, indicating the presence of other recessive resistance genes, probably derived from the recurrent parent Sanilac (Miklas et al. 2000). BRB130 is a breeding line with white seeds developed in CIAT (Cali, Colombia), carrying genes $I$ and $b c-3$, which confer total resistance to both potyviruses (Kelly 1997; Mukeshimana et al. 2005). Like Sanilac BC6-Are, line BRB130 did not show mosaics or necrotic reaction when inoculated with a local $\mathrm{BCM}$ isolate.

The 12 common bean anthracnose differential cultivars, proposed by Pastor-Corrales (1991), were used to confirm the identity of the $C$. lindemuthianum isolates. Cultivars Dubbele Witte and Widusa were used as control in resistance tests against BCM. Cultivar Widusa carries the $I$ gene and exhibits systemic necrosis when infected by strains of BCMNV (NL3, NL5, NL6 or NL8), while cultivar Dubbele Witte shows typical mosaics when infected with BCMV or BCMNV strains (Drijfhout 1978).
Breeding methods

Common bean is considered a highly self-pollinated species (Ferreira et al. 2000). Breeding programs were developed in two steps. In the first step, resistance genes to anthracnose and/or BCM were introgressed in line A25 using a backcrossing method (Fehr 1987), including six backcross generations followed by four self-pollinated generations with individual plant selection (fixation phase). Selection of plants was carried out using resistance tests or combining marker-assisted backcrossing and resistance tests. In the second step, pyramiding of different resistance genes was accomplished by a single cross between the lines obtained in the first step. Pyramiding was performed using a pedigree method (Fehr 1987), developing four selfpollinated generations, whereas in each generation individual plants were selected by combining marker-assisted selection (marker-assisted pyramiding) and resistance tests. Throughout the entire selection process plants with a seed phenotype similar to line A25 were selected preferably. Crosses were performed in greenhouse using artificial hybridization; the verification was accomplished by resistance tests, morphological or molecular markers.

\section{Anthracnose resistance test}

The local C. lindemuthianum races 3, 6, 19, 38, and 102 (Ferreira et al. 2008) were used in this work. Race 38, the most common in northern Spain, was used for the introgression of anthracnose genetic resistance. In addition, race 31 (described in Europe and previously denominated as kappa race; Balardin and Kelly 1997) was also used in pyramiding programs. To obtain abundant sporulation, all races were grown at $21^{\circ} \mathrm{C}$ in darkness for about 10 days in potato dextrose agar (Difco, Becton-Dickinson and Company, Sparks, MD USA). Spore suspensions were prepared by flooding the plates with $5 \mathrm{ml}$ of $0.01 \%$ Tween 20 (Sigma-Aldrich, St. Louis, MO USA) in sterile distilled water and scraping the surface of the culture with a spatula. Seeds of each genotype were sown in $4 \times 30 \times 40 \mathrm{~cm}$ plastic trays containing peat:perlite at 80:20. Inoculations were carried out on 8 to 10-day-old seedlings, when primary leaves were totally opened. Seedlings were sprayed with the aqueous conidial suspension containing $1.2 \times 10^{6}$ conidia $\mathrm{ml}^{-1}$ and maintained at $20-22^{\circ} \mathrm{C}$, at $95-100 \%$ humidity for $12 \mathrm{~h}$ photoperiod in a climatic chamber. Plant responses were evaluated after 7-9 days using a 1-9 scale where 1 is no visible symptoms and 9 very severely diseased or dead. Seedlings with no visible symptoms (severity value 1) or showing limited necrotic lesions (severity values 2-3) were considered resistant. Seedlings with large sporulating lesions (severity values 4-8) or dead (severity value 9) were considered susceptible. In each 
inoculation, the susceptible line A25 and the 12 differential cultivars (Pastor-Corrales 1991) were included as control.

\section{$\mathrm{BCM}$ resistance test}

A local strain (BCM-16), which produces necrotic reaction on the leaves in cultivar Widusa and typical mosaics in lines A25 and Dubbele Witte, was used in this work. This potyvirus was obtained from naturally infected plants of cultivar Andecha, and it was maintained in cultivar Dubbele Witte (Drijfhout 1978). Seedlings were grown in pots and inoculated by rubbing young unifoliate leaves with gauze dipped in a sap. Fresh inoculum was prepared according to Strausbaugh et al. (2003) from young trifoliate leaves of Dobbele Witte cultivar exhibiting strong mosaic symptoms. Inoculated plants were maintained above $22-28^{\circ} \mathrm{C}$ in climate chamber $(12 \mathrm{~h}$ photoperiod) during the 21 days. Dubbele Witte and Widusa cultivars were included as control of susceptibility in each inoculation. Plants with no visible symptoms (typical mosaic, necrotic reaction on the leaves or systemic necrosis) were considered resistant.

\section{Molecular marker analysis}

The following molecular markers were used: the dominant SCAR marker SW13 ${ }^{690}$, linked to the $I$ gene (Melotto et al. 1996); the dominant SCAR marker ROC $11^{420}$, linked in repulsion phase to the recessive $b c-3$ resistance allele (Johnson et al. 1997); the dominant CAP marker $\mathrm{SCH} 20^{1000}$ (obtained after Taq I digestion of amplification product), the dominant RAPD fragments $\mathrm{OM} 2^{1050}$, OQ04 ${ }^{600}$, and the SCAR SQ4 ${ }^{1440}$, linked to cluster $\mathrm{Co}-2$ (Adam-Blondon et al. 1994; Rodríguez-Suárez et al. 2007, 2008; Awale et al. 2008); the dominant SCAR markers $\mathrm{SI} 19^{460}, \mathrm{SB} 12^{350}$, linked to $\mathrm{Co}-3 / 9$ cluster (Miklas et al. 2000; Méndez de Vigo et al. 2005; Rodríguez-Suárez et al. 2008). Specific molecular markers were used in breeding programs once they were reported.

Genomic DNA was isolated from young leaves using the FastDNA ${ }^{\circledR}$ kit (MP Biomedicals, LLC, Illkirch, France) following the supplier's instructions. The PCR amplifications of these molecular markers were carried out as described by the corresponding authors. The PCR products were resolved on $2 \%$ agarose gels, stained with ethidium bromide or SYBR Safe DNA gel stain (Invitrogen, Oregon, USA) and visualized under UV light.

Morpho-agronomic traits

Recurrent parent (line A25), the five resistance sources (A252, A321, A493, Sanilac BC6-Are, and BRB130) and the obtained lines were grown at Villaviciosa, Asturias (northern Spain), during the spring-summer 2010 in order to characterize the genotypes in the same environment. Three replications, consisting of $12-15$ plants in a meterlong row for each genotype, were planted in a randomized complete block design. Genotypes were characterized considering the following morpho-agronomic traits: (i) market class, considering the classification reported by Voysest (2000); (ii) growth habit, classified as determinate (Type I), indeterminate erect (Type II), indeterminate prostrate (Type III), and indeterminate climbing (Type IV) according to Singh (1982); (iii) days to flowering and maturity, according to Pérez-Vega et al. (2010); (iv) pod length and number of seed per pod, average of 10 pods per replication; (v) seed length (average of 10 seed per replication) and 100-seed weight (average of 3 samples per replication).

\section{Data analysis}

Chi-square was used to test goodness-of-fit of observed segregations to expected ratios. LSD tests $(5 \%)$ were used to identify significant differences among means for the quantitative traits tested. Statistical analyses were carried out using the SPSS V12 software (Chicago, IL, USA).

\section{Results}

Introgression of resistance genes

Single resistant genes to anthracnose and/or BCM were introgressed in line A25 by mean of six parallel backcrossing programs (Fig. 1), and six breeding lines showing fabada seed phenotype were obtained. Figure 1 shows seed phenotypes of the five donor lines, the recurrent parent (line A25) and the obtained lines.

Lines A1183, A1258, A1220, and A1231 Genes conferring resistance to $C$. lindemuthianum local race 38 were introgressed into line A25 through four parallel backcrossing programs from resistance sources A252, A321, A493 and Sanilac BC6-Are (Fig. 1). In each backcross generation $\left(\mathrm{BC}_{n} \mathrm{~F}_{1}\right)$ resistant plants were identified using resistance tests conducted with race 38 . In the last backcross generation, the $\mathrm{BC}_{6} \mathrm{~F}_{1}$ plants showed a 1 resistant: 1 susceptible ratio segregation against race 38 (Table 1). One resistant plant was selected in each backcrossing program, and the corresponding $\mathrm{BC}_{6} \mathrm{~F}_{2}$ progeny showed a 3 resistant: 1 susceptible ratio segregation against race 38 (Table 1), indicating the introgression of one resistance gene. As a result of these parallel backcrossing programs, four resistant lines to race 38 were obtained; line A1231 from the donor line A321, line A1258 from line A252, line 
Fig. 1 Pedigree and seed phenotype of ten fabada breeding lines obtained in this work: lines A1231, A1258, A1220, A1183, A1878, A2418, A1699, A2438, A2806, and A3308. Line A25, proceeding from a selection of the landrace Andecha, is the recurrent parent belong to market class fabada. Genotypes A321, A252, A493, Sanilac BC6-Are, and BRB130 are the resistance sources used in the breeding programs. $B C$ backcrossing method, $S C$ pedigree method from a single cross, $\mathrm{Co}-2^{C}$ and $\mathrm{Co}-2^{A 252}$, anthracnose resistance gene included in the cluster $\mathrm{Co}-2$ derived from line Sanilac BC6Are and line A252, respectively; Co-3/9, anthracnose resistance gene included in the cluster $\mathrm{Co}$ $3 / 9 ; I, b c-3$, resistance genes to bean common mosaic (potyvirus BCMV and BCMNV). Seeds came from of the evaluation carried out at Villaviciosa, Asturias, Spain, during the spring 2010. White bar $1 \mathrm{~cm}$

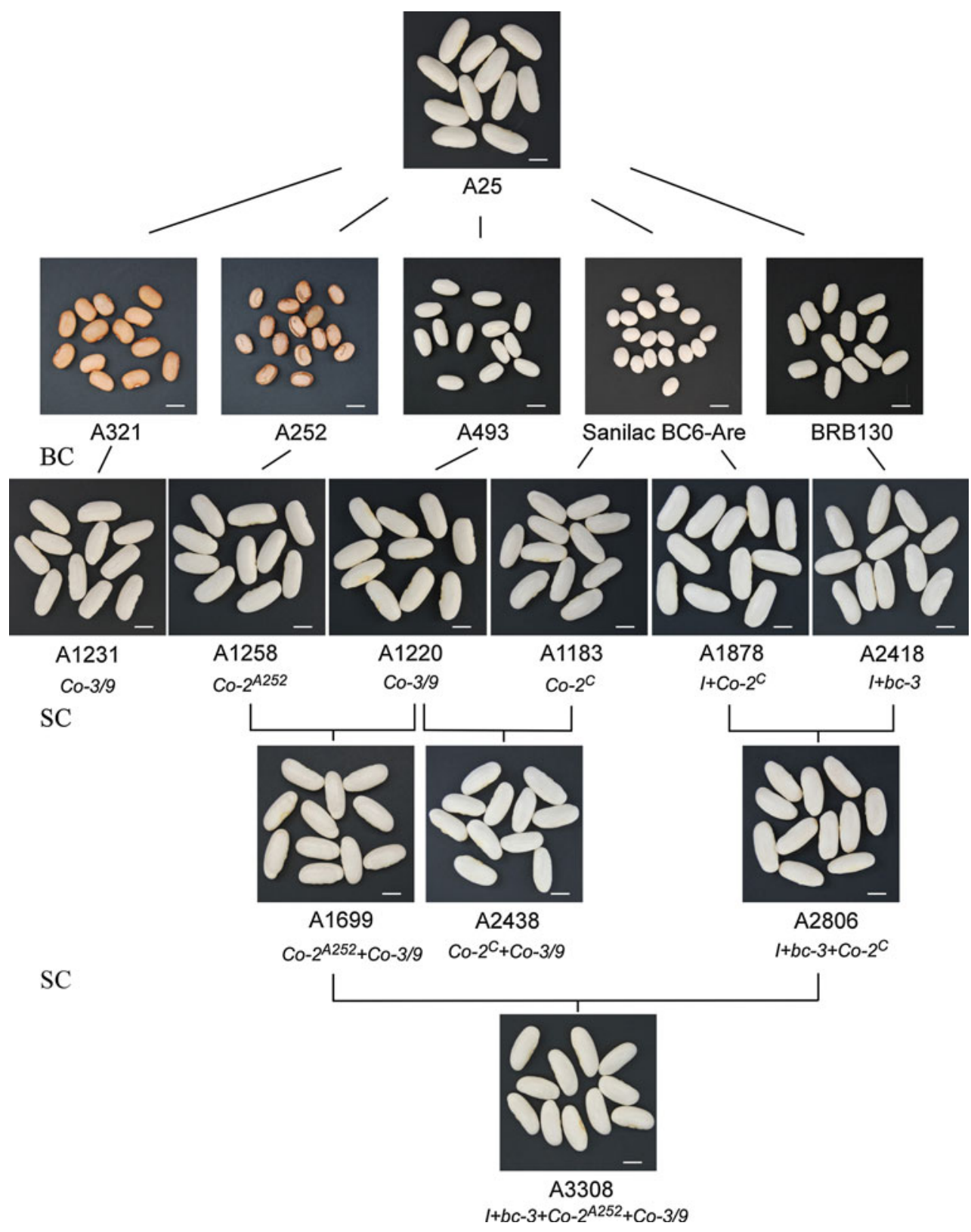

A1220 from the line A493, and line A1183 from the line Sanilac BC6-Are. Table 2 shows the resistance response against $C$. lindemuthianum races 3, 6, 19, 38, 102, and 31 of the five donor lines, the recurrent parent (line A25) and the obtained lines. According to Méndez de Vigo et al. (2005), lines A1220 and A1231 carry one resistance gene to race 38 located in cluster Co-3/9. Line A1183 carries the Co-2 gen derived from Sanilac BC6-Are. Line A1258 carries only one of the two resistance genes to race 38 present in the donor line A252 and one resistance gene to race 31.

Line A1878 Genes conferring resistance to $C$. lindemuthianum race 38 and to $\mathrm{BCM}$ were introgressed into line
A25 from the resistant source Sanilac BC6-Are through a fifth backcrossing program (Fig. 1). In each backcross generation $\left(\mathrm{BC}_{n} \mathrm{~F}_{1}\right)$, selections were carried out combining anthracnose resistance tests (race 38) and marker-assisted backcrossing based on the SCAR marker SW13 ${ }^{690}$ (linked in coupling phase to gene $I$ ). Resistant plants against race 38 were analyzed for the SCAR marker SW13 ${ }^{690}$, and those showing the amplification product were selected. The corresponding progenies of the selected plants were tested for response to $\mathrm{BCM}-16$ in order to verify the resistance response. In the last backcross generations $\left(\mathrm{BC}_{6} \mathrm{~F}_{1}\right.$ and $\mathrm{BC}_{6} \mathrm{~F}_{2}$ ), observed segregations for the reaction to race 38 
Table 1 Observed segregation for the response to anthracnose race 38 and observed segregation for molecular markers SW13 ${ }^{690}$ and ROC $11^{420}$ in $\mathrm{BC}_{6} \mathrm{~F}_{1}$ plants obtained from crosses between the selected $\mathrm{BC}_{5} \mathrm{~F}_{1}$ plants and the recurrent parent (line $\mathrm{A} 25$ ) in the six parallel backcrossing programs

\begin{tabular}{|c|c|c|c|c|c|c|c|c|c|c|c|c|}
\hline \multirow[t]{3}{*}{ Resistance sources } & \multicolumn{4}{|c|}{$\mathrm{BC}_{6} \mathrm{~F}_{1}$} & \multirow{3}{*}{$\mathrm{BC}_{6} \mathrm{~F}_{1}$ selected plant } & \multicolumn{6}{|c|}{$\mathrm{BC}_{6} \mathrm{~F}_{2}$} & \multirow{3}{*}{ Obtained line } \\
\hline & \multicolumn{2}{|c|}{ Race 38} & \multicolumn{2}{|c|}{ SW13690 a } & & \multicolumn{2}{|c|}{ Race 38} & \multicolumn{2}{|c|}{ SW13 690 a } & \multicolumn{2}{|c|}{$\mathrm{ROC} 11^{420 \mathrm{~b}}$} & \\
\hline & $\mathrm{R}$ & $S$ & + & - & & $\overline{\mathrm{R}}$ & $\bar{S}$ & + & - & + & - & \\
\hline A 252 & 20 & 28 & & & 1258 & 40 & 10 & & & & & A1258 \\
\hline A321 & 19 & 25 & & & 1231 & 36 & 12 & & & & & A1231 \\
\hline A493 & 7 & 5 & & & 1220 & 28 & 10 & & & & & A1220 \\
\hline Sanilac BC6-Are & 6 & 6 & & & 1183 & 21 & 9 & & & & & A1183 \\
\hline Sanilac BC6-Are & 8 & 5 & 3 & 4 & 1878 & 54 & 17 & 35 & 13 & & & A1878 \\
\hline BRB130 & & & 11 & 15 & 2418 & & & 38 & 11 & 25 & 7 & A2418 \\
\hline
\end{tabular}

Observed segregation in the corresponding $\mathrm{BC}_{6} \mathrm{~F}_{2}$ population derived from selected $\mathrm{BC}_{6} \mathrm{~F}_{1}$ in the six parallel backcrossing programs. Significant differences $(p<0.05)$ from the expected ratio $\left(1: 1\right.$ in $\mathrm{BC}_{6} \mathrm{~F}_{1}$ plants, and 3:1 in $\left.\mathrm{BC}_{6} \mathrm{~F}_{2}\right)$ were not found in all cases

${ }^{\text {a }}$ Resistant plants to race 38 were only analyzed

b Plants with the marker SW $13^{690}$ were only analyzed

+ presence of specific fragment, - absence of specific fragment, $R$ resistant, $S$ susceptible

Table 2 Reaction against six C. lindemuthianum races and a local isolate of common mosaic viruses in the recurrent parent (line A25), the five resistance sources (A252, A321, A493, Sanilac BC6-Are, and

\begin{tabular}{|c|c|c|c|c|c|c|c|c|}
\hline \multirow[t]{2}{*}{ Genotypes } & \multirow[t]{2}{*}{ Type } & \multicolumn{6}{|c|}{ Anthracnose races } & \multirow{2}{*}{$\begin{array}{l}\text { BCMV/ } \\
\text { BCMNV }\end{array}$} \\
\hline & & 3 & 6 & 19 & 38 & 102 & 31 & \\
\hline A252 & Donor & $\mathrm{R}$ & $\mathrm{R}$ & $\mathrm{R}$ & $\mathrm{R}$ & $\mathrm{R}$ & $\mathrm{R}$ & - \\
\hline A321 & Donor & $\mathrm{R}$ & $\mathrm{R}$ & $\mathrm{R}$ & $\mathrm{R}$ & $\mathrm{R}$ & $\mathrm{R}$ & - \\
\hline A493 & Donor & $\mathrm{R}$ & $\mathrm{R}$ & $\mathrm{R}$ & $\mathrm{R}$ & $\mathrm{R}$ & $\mathrm{R}$ & - \\
\hline Sanilac BC6-Are & Donor & $\mathrm{R}$ & $\mathrm{R}$ & $\mathrm{R}$ & $\mathrm{R}$ & $\mathrm{R}$ & $\mathrm{S}$ & - \\
\hline BRB130 & Donor & $\mathrm{S}$ & $\mathrm{S}$ & $\mathrm{S}$ & $\mathrm{R}$ & S & $\mathrm{S}$ & - \\
\hline A 25 & Recurrent & $\mathrm{R}$ & $\mathrm{S}$ & $\mathrm{R}$ & S & $\mathrm{R}$ & $\mathrm{S}$ & + \\
\hline A1183 & NB line & $\mathrm{R}$ & $\mathrm{R}$ & $\mathrm{R}$ & $\mathrm{R}$ & $\mathrm{R}$ & $\mathrm{S}$ & + \\
\hline A 1220 & NB line & $\mathrm{R}$ & $\mathrm{R}$ & $\mathrm{R}$ & $\mathrm{R}$ & $\mathrm{R}$ & $\mathrm{S}$ & + \\
\hline A1231 & NB line & $\mathrm{R}$ & $\mathrm{R}$ & $\mathrm{R}$ & $\mathrm{R}$ & $\mathrm{R}$ & $\mathrm{S}$ & + \\
\hline A 1258 & NB line & $\mathrm{R}$ & $\mathrm{R}$ & $\mathrm{R}$ & $\mathrm{R}$ & $\mathrm{R}$ & $\mathrm{R}$ & + \\
\hline A 1878 & NB line & $\mathrm{R}$ & $\mathrm{R}$ & $\mathrm{R}$ & $\mathrm{R}$ & $\mathrm{R}$ & $\mathrm{S}$ & - \\
\hline A2418 & NB line & $\mathrm{R}$ & $\mathrm{S}$ & $\mathrm{R}$ & $\mathrm{S}$ & $\mathrm{R}$ & $\mathrm{S}$ & - \\
\hline A2438 & NB line & $\mathrm{R}$ & $\mathrm{R}$ & $\mathrm{R}$ & $\mathrm{R}$ & $\mathrm{R}$ & $\mathrm{S}$ & + \\
\hline A1699 & NB line & $\mathrm{R}$ & $\mathrm{R}$ & $\mathrm{R}$ & $\mathrm{R}$ & $\mathrm{R}$ & $\mathrm{R}$ & + \\
\hline A2806 & NB line & $\mathrm{R}$ & $\mathrm{R}$ & $\mathrm{R}$ & $\mathrm{R}$ & $\mathrm{R}$ & $\mathrm{S}$ & - \\
\hline A3308 & NB line & $\mathrm{R}$ & $\mathrm{R}$ & $\mathrm{R}$ & $\mathrm{R}$ & $\mathrm{R}$ & $\mathrm{R}$ & - \\
\hline
\end{tabular}

+ Symptoms of bean common mosaic, - no symptoms, $R$ resistant reaction to specific race, $S$ susceptible reaction

and the expression of marker SW13 ${ }^{690}$ fitted to a monogenic segregation (Table 1).

Line A2418 Two genes conferring resistance to $\mathrm{BCM}$ were introgressed in line A25 from the resistance source BRB130 through a sixth backcrossing program (Fig. 1). The gene combination $I+b c-3$ was introgressed with the help of the SCAR markers SW $13^{690}$ and ROC $11^{420}$ (linked in coupling phase to $B c-3$ allele). In each backcrossing
BRB130) used as donors, and the ten new breeding lines obtained (NB line) through introgression and pyramiding 
was also found in the last backcross generation for the segregation of both molecular markers (Table 1).

\section{Pyramiding of resistance genes}

Pyramiding of specific resistance genes was carried out, and four breeding lines showing a seed phenotype included in the market class fabada were obtained (see Fig. 1).

Line A2438 Two independent anthracnose resistance genes from the breeding lines A1183 and A1220, conferring resistance to race 38 , were pyramided into line A2438 (Fig. 1). According to their pedigree, lines A1183 and A1220 carry different resistance loci to anthracnose, located in cluster Co-2 and Co-3/9, respectively. Segregation to race 38 (100 resistant: 7 susceptible; $\chi_{15: 1}^{2}=0.00$, $p=0.89$ ) was observed in a $\mathrm{F}_{2}$ population, derived from the cross between lines A1183 and A1220, confirming that both breeding lines carry independent resistance loci. Pyramiding of two genes was conducted with the following molecular markers: SB12 ${ }^{350}$ linked in coupling phase to gene $C o-3 / 9$, the RAPD fragment OQ04 ${ }^{600}$ and SCAR SQ04 ${ }^{1440}$ linked in repulsion phase and in coupling phase to locus $\mathrm{Co}-2$, respectively (see Table 3 ). Among the $\mathrm{F}_{2}$-resistant plants to race 38,62 were self-pollinated and checked for the expression of the three markers. Plants showing the marker combination $\mathrm{SB} 12^{350+}, \mathrm{OQ} 04^{600-}$ and $\mathrm{SQ} 04^{1440+}$ (probable genotype $\mathrm{Co}-3 / 9-\mathrm{Co}-2 \mathrm{Co}-2$ ) were pre-selected. The corresponding $\mathrm{F}_{2: 3}$ progenies $\left(20-22 \mathrm{~F}_{3}\right.$ plants derived from each selected $\mathrm{F}_{2}$ plant) were also analyzed for marker expression in order to identify homozygous genotypes, and four of them were selected. Two additional self-crossing generations considering seed phenotype (size and shape of seeds) and following a pedigree method were performed from these four homozygous $F_{2}$ plants. Line A2438 was obtained from one selected $\mathrm{F}_{4}$ plant. Resistance to race 38 was verified in the selected plants using anthracnose resistance tests.

Line A1699 Two independent anthracnose resistance genes from the breeding lines A1258 and A1220, conferring resistance to race 38, were pyramided in line A1699 (Fig. 1). According to their pedigree, lines A1258 and A1220 carry different resistance loci to anthracnose, located in cluster Co-2 and Co-3/9, respectively. A segregation in the response to race 38 corresponding to two independent resistant loci (147 resistant plants: 7 susceptible plants; $\chi_{15: 1}^{2}=0.76, p=0.38$ ) was observed in a $\mathrm{F}_{2}$ population derived from the cross A1258 $\times$ A 1220 . Pyramiding of resistance genes was conducted combining the molecular marker analysis (marker SB12 linked to $\mathrm{Co}-3 / 9$ ) and resistance tests against race 31 ( $\mathrm{Co}-2$ from line A252). A total of $220 \mathrm{~F}_{2}$ plants derived from the cross A1258 $\times$ A1220 were self-crossed and 61 were selected considering the $F_{3}$ seed phenotype. The $F_{2: 3}$ progenies of these 61 plants were tested against the anthracnose race 31, and a segregation corresponding to one resistance gene (12 homozygous resistant: 32 heterozygous: 17 homozygous susceptible; $\chi_{1: 2: 1}^{2}=0.96, p=0.61$ ) was observed. The $\mathrm{F}_{2: 3}$ progenies derived from the 12 homozygous resistant plants (genotype $\mathrm{Co}-2 \mathrm{Co}-2$ ) were analyzed for the expression of the molecular marker SB12 $2^{350}$, linked to Co-3/9 gene. Two $F_{2}$ plants were homozygous for this marker (probably genotype $\mathrm{Co}-3 / 9 \mathrm{Co}-3 / 9$ ). Two additional self-crossing generations considering seed phenotype (size and shape of seeds) and following a pedigree method were performed from these homozygous $F_{2}$ plants, and line A1699 was obtained from one selected $\mathrm{F}_{4}$ plant. Resistance to races 31 and 38 was verified in the selected plants using anthracnose resistance tests.

Line A2806 From the breeding lines A1878 and A2418 two independent genes involved in the resistance against anthracnose ( $\mathrm{Co}-2)$ and $\mathrm{BCM}(b c-3)$ were pyramided into line A2806 (Fig. 1). Both lines carry the I gene (see Fig. 1; Table 3). Pyramiding of resistance genes was conducted combining resistance tests and MAS, based on the SCAR markers SCH $20^{1000}$ (linked in coupling phase to the $\mathrm{Co}-2$ gene) and ROC $11^{420}$ (linked in coupling phase to the $B c-3$ allele). A total of $224 \mathrm{~F}_{2}$ plants derived from the cross A1878 $\times$ A2418 were tested against race 38 and a segregation corresponding to one dominant resistance gene (171 resistant: 53 susceptible; $\chi_{3: 1}^{2}=0.21, p=0.64$ ) was observed. The 171 resistant plants (homozygous resistant or heterozygous; $\mathrm{R}^{38}$ or $\mathrm{R} / \mathrm{S}^{38}$ ) were analyzed for the two molecular markers and self-pollinated. All plants expressed marker $\mathrm{SCH} 20^{1000}$, confirming a close linkage relationship between the marker and the $\mathrm{Co}-2$ locus. For marker ROC $11^{420}$, a segregation corresponding to one locus was observed (131 ROC $11^{420+}$ : $36 \mathrm{ROC} 11^{420-} ; \chi_{3: 1}^{2}=1.06$, $p=0.30$ ). Among the $36 \mathrm{~F}_{2}$ plants lacking the amplification product of ROC $11^{420}$ (probably genotype $b c-3 b c-3$ ), six were selected based on their seed phenotype and selfpollinated. The corresponding $\mathrm{F}_{2: 3}$ progenies were tested again for the response to race 38 resulting in two homozygous resistant plants (genotype $\mathrm{Co}-2 \mathrm{Co}-2$ ). Two additional self-crossing generations considering seed phenotype (size and shape of seeds) and following a pedigree method were performed from these two plants and line A2806 was obtained from one selected $\mathrm{F}_{4}$ plant. In each generation, resistance was verified by testing anthracnose resistance against race 38 and resistance to the local isolate of BCM. In selected families, mosaic or systemic necrosis were not observed in the BCM tests.

Line A3308 From the breeding lines A2806 (I+ $\left.b c-3+\mathrm{Co}^{2} 2^{C}\right)$ and A1699 $\left(\mathrm{Co}-2^{A 252}+\mathrm{Co}-3 / 9\right)$ four independent loci conferring resistance against anthracnose 
Table 3 Expression of seven molecular markers linked to the four resistance loci introgressed or pyramided in the fabada line A25, five resistant sources (A252, A321, A493, Sanilac BC6-Are, and BRB130) used as donors, and the ten fabada breeding lines (NB line) obtained

\begin{tabular}{|c|c|c|c|c|c|c|c|c|c|}
\hline Lines & Type & $\begin{array}{l}\text { SW13 } \\
690 \mathrm{pb} \\
I\end{array}$ & $\begin{array}{l}\text { ROC } 11 \\
420 \mathrm{pb} \\
b c-3\end{array}$ & $\begin{array}{l}\mathrm{SQ} 4 \\
1,440 \mathrm{pb} \\
\mathrm{Co}-2^{C}\end{array}$ & $\begin{array}{l}\mathrm{SCH} 20 \\
1,000 \mathrm{pb} \\
\mathrm{Co}-2^{C}\end{array}$ & $\begin{array}{l}\mathrm{OM} 2 \\
1,050 \mathrm{pb} \\
\mathrm{Co}-2^{A 252}\end{array}$ & $\begin{array}{l}\text { SI19 } \\
460 \mathrm{pb} \\
\text { Co-3/9 }\end{array}$ & $\begin{array}{l}\mathrm{SB} 12 \\
350 \mathrm{pb} \\
\text { Co-3/9 }\end{array}$ & Inferred genotype \\
\hline A252 & Donor & + & - & + & - & - & - & + & \\
\hline A 321 & Donor & + & - & - & + & - & - & + & \\
\hline A493 & Donor & - & + & + & + & - & + & + & \\
\hline Sanilac BC6-Are & Donor & + & - & + & + & - & + & - & \\
\hline BRB130 & Donor & + & - & - & - & - & - & + & \\
\hline A25 & Recurrent & - & + & - & - & + & + & - & \\
\hline A1183 & NB line & - & + & + & + & + & + & - & $\mathrm{Co}-2^{C}$ \\
\hline A1220 & NB line & - & + & - & - & + & + & + & $\mathrm{Co}-3 / 9$ \\
\hline A1231 & NB line & - & + & - & - & + & - & + & Co-3/9 \\
\hline A 1258 & NB line & - & + & - & - & - & + & - & Co- $2^{A 252}$ \\
\hline A1878 & NB line & + & + & + & + & - & + & - & $I+C o-2^{C}$ \\
\hline A2418 & NB line & + & - & - & - & + & + & - & $I+b c-3$ \\
\hline A1699 & NB line & - & + & + & - & - & + & + & $\mathrm{Co}-2^{A 252} \mathrm{Co}-3 / 9$ \\
\hline A2438 & NB line & - & + & + & + & + & + & + & $\mathrm{Co}-2+\mathrm{Co}-3 / 9$ \\
\hline A2806 & NB line & + & - & + & + & + & + & - & $I+b c-3+C o-2^{C}$ \\
\hline A 3308 & NB line & + & - & + & + & - & + & + & $I+b c-3+C o-2^{A 252}+C o-3 / 9$ \\
\hline
\end{tabular}

The inferred genotype for the resistance to anthracnose and the bean common mosaic is indicated

+ Presence, - absence of the specific fragment, $N B$ Line new breeding lines

and BCM were pyramided in line A3308 (Fig. 1). Pyramiding of resistance genes was conducted combining resistance tests and MAS, based on the SCAR markers SW13 ${ }^{690}$, ROC $11^{420}$ and SB $12^{350}$ linked to loci $I, b c-3$ and $C o-3 / 9$, respectively. A total of $308 \mathrm{~F}_{2}$ plants derived from the cross A2806 $\times$ A1699 were self-crossed in field and naturally infected with BCM, and 238 of them did not show typical mosaic symptoms caused by BCM. Among them, 96 were selected considering the seed phenotype of the corresponding $\mathrm{F}_{2: 3}$ progenies which were tested against race 31 (16-20 $\mathrm{F}_{3}$ seedling derived from each $\mathrm{F}_{2}$ plant) for the identification of cluster $\mathrm{Co}-2^{A 252}$. A segregation corresponding to one locus was observed (20 homozygous resistant: 45 heterozygous: 28 homozygous susceptible; $\left.\chi_{1: 2: 1}^{2}=1.46, p=0.48\right)$. Presence of the molecular markers $\mathrm{SW} 13^{690}, \mathrm{ROC} 11^{420}$ and SB12 ${ }^{350}$ was analyzed in the 20 homozygous resistant $F_{2}$ plants. All of them carried SW $13^{690}$ marker linked to the $I$ gene while segregation was observed for markers ROC $11^{420}$ and SB $12^{350}$. Seven plants showing the marker combination ROC $11^{420-} \mathrm{SB} 12^{350+}$ (probably genotype $I-b c-3 b c-3 C o-3 / 9-)$ were pre-selected and the corresponding $\mathrm{F}_{2: 3}$ progenies $\left(45-50 \mathrm{~F}_{3}\right.$ plants per $\mathrm{F}_{2}$ plant) were self-crossed in field and analyzed for the three molecular markers. Two families were homozygous for the three markers (probably genotype II Co-9Co-9 bc-3bc-3). In these two families, resistance was verified by testing anthracnose resistance against race 31 and resistance to the local isolate of BCM. Systemic necrosis was not observed in these BCM tests in selected progenies. After one additional self-pollinated generation using a pedigree method, line A3308 was obtained from one $\mathrm{F}_{4}$ selected plant.

Morpho-agronomic characterization

Recurrent parent, the five lines used as donors, and the ten obtained lines were characterized for eight morpho-agronomic traits (Table 4). The ten obtained lines showed an indeterminate growth habit type IV and oblong, white and very large seeds with a 100-seed weight between 90 and $105 \mathrm{~g}$. Seed phenotype of the ten lines belong to the market class fabada (Fig. 1). Analysis of variance among 11 fabada lines (A25 and breeding lines) only revealed significant differences for the traits days to maturity, pod length and seed length. Line A25 was significantly earlier than the six breeding lines A1183, A1220, A1699, A2418, A2438 and A3308. Lines A1220 and A1699 showed pod length significantly lower than line A25. Lines A1699 and A2438 showed a seed length significantly lower than line A25 while line A3308 showed a significant seed length higher than the recurrent parent. Significant differences were not found for the traits days to flowering, seed per pod and 100 -seed weight. 
Table 4 Results of the characterization using eight morpho-agronomic traits in the fabada line A25, the five resistant sources (A252, A321, A493, Sanilac BC6-Are, and BRB130) used as donors, and the ten new breeding lines obtained (NB lines)

\begin{tabular}{|c|c|c|c|c|c|c|c|c|c|}
\hline Lines & Type & $\begin{array}{l}\text { Market } \\
\text { class }\end{array}$ & $\begin{array}{l}\text { Growth } \\
\text { habit }\end{array}$ & $\begin{array}{l}\text { Days to } \\
\text { flowering }\end{array}$ & $\begin{array}{l}\text { Days to } \\
\text { maturity }\end{array}$ & $\begin{array}{l}\text { Pod length } \\
(\mathrm{cm})\end{array}$ & $\begin{array}{l}\text { Seeds } \\
\text { per pod }\end{array}$ & $\begin{array}{l}\text { Seed } \\
\text { length }(\mathrm{mm})\end{array}$ & $\begin{array}{l}\text { 100-seed } \\
\text { weight }(\mathrm{g})^{\mathrm{a}}\end{array}$ \\
\hline A252 & Donor & ojo de cabra & III & 58.7 & 117.0 & 9.6 & 5.4 & 11.1 & 30.2 \\
\hline A321 & Donor & - & III & 77.0 & 143.0 & 10.9 & 5.0 & 12.7 & 40.1 \\
\hline A493 & Donor & laran & I & 61.7 & 121.3 & 9.1 & 3.4 & 13.4 & 40.5 \\
\hline Sanilac BC6-Are & Donor & navy & I & 47.3 & 107.0 & 8.0 & 4.6 & 8.7 & 24.3 \\
\hline BRB130 & Donor & white kidney & I & 45.0 & 118.0 & 10.3 & 4.1 & 14.3 & 50.5 \\
\hline A25 & Recurrent & fabada & IV & 73.7 & 124.3 & 15.2 & 3.5 & 21.5 & 93.3 \\
\hline A1183 & NB line & fabada & IV & 71.5 & 131.5 & 14.1 & 2.6 & 22.1 & 105.6 \\
\hline A1220 & NB line & fabada & IV & 75.0 & 142.3 & 12.6 & 2.9 & 21.4 & 100.0 \\
\hline A1231 & NB line & fabada & IV & 71.3 & 121.0 & 14.2 & 3.2 & 21.1 & 94.5 \\
\hline A1258 & NB line & fabada & IV & 75.0 & 129.7 & 14.5 & 3.2 & 21.5 & 96.1 \\
\hline A1878 & NB line & fabada & IV & 74.0 & 128.7 & 14.3 & 2.8 & 22.4 & 99.3 \\
\hline A2418 & NB line & fabada & IV & 76.0 & 136.3 & 14.4 & 2.6 & 21.8 & 91.9 \\
\hline A2438 & NB line & fabada & IV & 72.7 & 138.3 & 14.4 & 2.8 & 22.0 & 101.4 \\
\hline A1699 & NB line & fabada & IV & 74.7 & 141.5 & 13.6 & 2.9 & 19.9 & 88.6 \\
\hline A2806 & NB line & fabada & IV & 73.0 & 132.7 & 15.4 & 2.6 & 21.6 & 97.1 \\
\hline A3308 & NB line & fabada & IV & 70.3 & 139.3 & 14.3 & 2.7 & 23.4 & 102.8 \\
\hline $\operatorname{LSD}(0.05)^{\mathrm{b}}$ & & & & ns & 6.98 & 1.25 & ns & 0.96 & ns \\
\hline
\end{tabular}

${ }^{a}$ Moisture content of $14-15 \%$

${ }^{\mathrm{b}}$ Donor lines were not included in the statistical analysis

Response to races of $C$. lindemuthianum and BCM

Recurrent parent, the five resistance donors, and the ten obtained lines were jointly evaluated against the six races of C. lindemuthianum 3, 6, 19, 31, 38, and 102 (Table 2). Donor lines A252, A321 and A493 were resistant to the six races, cultivar Sanilac BC6-Are was resistant to all races except to race 31 , and line BRB130 only showed resistance to race 38. Recurrent line A25 was susceptible to races 6, 38 and $31\left(R^{3} S^{6} R^{19} S^{38} R^{102} S^{31}\right)$. This resistance spectrum was maintained in breeding line A2418, derived from BRB130 (Fig. 1). Lines A1183, A1220, A1231, A1878, A2438 and A2806 were resistant to all races except to race $31\left(R^{3} R^{6} R^{19} R^{38} R^{102} S^{31}\right)$. Lines A1258, A1699, and A3308, all of them derived from A252, were resistant to all races $\left(R^{3} R^{6} R^{19} R^{38} R^{102} R^{31}\right)$. Concerning the reaction to the local strain of BCM (BCM-16), lines A25, A1183, A1220, A1231, A1258, A2438, and A1699 showed mosaic symptoms after inoculation. The five donor lines and the breeding lines A1878, A2418, A2806, and A3308 did not show evidence of mosaic or necrotic reaction in the resistance tests.

Molecular marker differentiation

The 11 fabada lines were differentiated among them using a set of 7 molecular markers linked to the 4 loci introgressed and pyramided. Table 3 shows the profiles of these seven molecular markers in each one of the fabada lines and the donor lines. The expression of the seven molecular markers was consistent with the pedigree of each breeding line. Donor lines Sanilac BC6-Are and BRB130 showed amplification product for markers SW $13^{690}$, linked to the $I$ gene, and lacked amplification product for ROC $11^{420}$, linked to the $b c-3$ gene. This profile was maintained in lines A2418, A2806 and A3308, originally derived from BRB130. For these markers, the remaining lines maintained the profile of the recurrent parent, except line A1878 which showed amplification products for both markers. Donor lines A252, A321 and A493 showed amplification product for marker SB12 $2^{350}$ and line A493 also showed amplification product for marker SI $19^{460}$, both markers linked to the Co-3/9 gene. The SB12 and SI19 marker profile of line A493 was maintained in the derived lines A1220, A1699, A2438, and A3308. Line A1231 had the marker profile of their donor line A321. Donor line Sanilac BC6-Are showed amplification product for markers $\mathrm{SCH} 20^{1000}$ and SQ4 ${ }^{1440}$, linked to $\mathrm{Co}-2$ gene. Both markers were present in the derived lines A1183, A1878, A2438, A2806, and A3308. The RAPD fragment OM2 ${ }^{1050}$ linked in repulsion phase to $\mathrm{Co}-2$ gene was present in the recurrent parent (line A25) and absent in the five donor lines. Lines A1258, A1699 and A3308, derived from A252, and line A1878, derived from Sanilac BC6-Are, did not 
show this amplification product. The remaining six breeding lines showed amplification for this fragment.

\section{Discussion}

Resistance genes against anthracnose and/or BCM were introgressed and accumulated in fabada line A25 by the use of conventional breeding methods. As a result of these breeding programs 10 fabada lines carrying resistance genes were obtained. In line A3308 the maximum of four resistance genes, two against anthracnose and two against BCM, were pyramided. Selection of resistant plants was carried out using resistance tests and marker-assisted selection or a combination of both. Breeding strategies were adapted regarding the availability of resources and tools like polymorphic molecular markers or greenhouse and climatic chamber space. The development of the breeding process was supported by previous knowledge of resistance genetic control: genes involved in plant response, its localization and organization in the genetic map and molecular markers linked to the corresponding genes. Based on knowledge about genetic control of resistance in donor lines, observed segregations in the last backcross generations, reactions against pathogens and the expression of specific molecular markers, it was possible to infer the genotype of each line.

Two resistance genes located in clusters Co-3/9 (LG04) and Co-2 (LG11) were used to introgress anthracnose genetic resistance in line A25. Introgression of genes $\mathrm{Co}$-3/ 9 (from lines $\mathrm{A} 493$ or A321) or $\mathrm{Co}-2$ (from Sanilac BC6-Are) lead to resistance against local races 6 and 38. Introgression of a gene located in cluster Co-2 from line A252 leads to resistance against races 6, 31 and 38. These results agree with the previously described organization in clusters of closely linked race-specific genes (Geffroy et al. 1999; Rodríguez-Suárez et al. 2007, 2008; Campa et al. 2009, 2010; David et al. 2009).

Line A1220, derived from line A493, carries one dominant resistance gene for the response to race 38 , deduced from the monogenic segregation observed in the last backcross generation. After the development of line A1220, Méndez de Vigo et al. (2005) described that the resistance to race 38 in line A493 is conferred by one dominant gene located in cluster Co-3/9 and linked in the coupling phase to marker SB12 $2^{350}$. The amplification product of marker SB12 $2^{350}$ is also present in line A1220, consequently it can be concluded that $\mathrm{Co}-3 / 9$ is the gene conferring resistance to race 38 in this line. The remaining lines (A1699, A2438, and A3308) originally derived from line A493 also show a resistance reaction against race 38 and express marker SB12 $2^{350}$, indicating the presence of a resistance gene included in cluster Co-3/9. Similarly, it can be deduced that the resistance gene $\mathrm{Co}-3 / 9$ is present in line A1231, derived from line A321. The lack of segregation in the response against race 38 observed in the $F_{2}$ population A1220 × A1231 (Méndez de Vigo et al. 2005) supports the hypothesis that both lines share the same resistance locus or two closely linked loci.

The inheritance of anthracnose resistance in line A252 was studied by Rodríguez-Suárez et al. (2007), concluding that resistance to race 38 is conferred by two independent dominant genes located in clusters Co-3/9 and Co-2, respectively. In addition, line A252 carries one dominant resistant gene against race 31 located in cluster Co-2. Line A1258, derived from A252, carries only one dominant resistance gene for the response to race 38 , deduced from the monogenic segregation observed in the last backcross generation. In the $\mathrm{F}_{2}$ population derived from the cross A1220 $\times$ A 1258 , the segregation for resistance to race 38 fitted to the expected ratio for two independent dominant genes, indicating that the introgressed resistance gene in line A1258 is independent of locus Co-3/9 carrying A1220. Consequently, the resistance to race 38 of the A1258 line is conferred by a gene located in cluster Co-2. Line A1258 also shows a resistance response against race 31 confirming the presence of one anthracnose resistance gene in cluster Co-2. Lines A1699 and A3308, originally derived from line A252, carry this Co-2 cluster with a resistance gene against race 31 (see Table 2).

Lines A1183 and A1878, obtained from donor line Sanilac BC6-Are, carry one dominant resistance gene for the response to race 38 , deduced from the monogenic segregation observed in the last backcross generation. According to the genealogical relationship of line Sanilac BC6-Are (Aylesworth et al. 1983) the Co-2 gene is present in lines A1183 and A1878. The amplification products of markers SQ4 ${ }^{1440}$ and $\mathrm{SCH} 20^{1000}$, linked in coupling phase to loci $\mathrm{Co}-2$ in donor line Sanilac BC6-Are, are expressed in all derived lines with resistance to race 38 (A1183, A1878, A2438, A2806 and A3308) supporting the presence of this resistance gene. The marker OM2 $2^{1050}$ is linked in repulsion phase to gene $\mathrm{Co}-2$ in Sanilac BC6-Are and is also absent in the derived lines except in A1183, probably due to recombination events.

Two genes, $I$ and $b c-3$, were used to introgress genetic resistance to BCM in fabada line A25. Donor line BRB130 shows the amplification product for SCAR marker SW13 ${ }^{690}$ (linked in coupling phase to the $I$ allele), and lacks that of SCAR marker ROC $11^{420}$ (linked in repulsion phase to the $b c-3$ allele). Lines A2418, A2806 and A3308, originally derived from line BRB130, were resistant to a local strain of BCM without showing evidence of mosaics or systemic necrosis, and the same molecular profile than BRB130 for the markers SW13 ${ }^{690}$ and ROC $11^{420}$. These results suggest that the resistance to BCM in lines A2418, 
A2806 and A3308 can be conferred by the gene combination $I+b c-3$. Line A1878 maintains resistance to BCM of its donor parent Sanilac BC6-Are, and expresses the amplification product of marker SW13 ${ }^{690}$. Evidences of systemic necrosis neither were found in donor line Sanilac BC6-Are and line A1878 suggesting that, apart from the $I$ gene, these lines can carry other additional recessive loci (bc-1, bc-2 or $b c-3)$ involved in the response to BCM. Donor line Sanilac BC6-Are can carry a recessive gene since derived from a backcrossing program using the navy bean Sanilac as recurrent parent, which shows resistant response conferred by the genotype $b c-u b c-2$ (Miklas et al. 2000; Strausbaugh et al. 2003). However, the recessive gene conferring resistance in line A1878 may have derived from the recurrent parental line A25, so that this recessive gene only would confer resistance to BCM in combination with the $I$ allele.

The ten new breeding lines showed a phenotype similar to line A25 regarding the eight morphological traits evaluated. Significant differences to the recurrent parent were only found in three morpho-agronomic traits: days to maturity, pod length and seed length. However, six backcrossing generations were necessary to recover the fabada seed phenotype. This observation suggests that numerous QTLs with small effect in the expression of seed phenotype could be involved in the genetic control of this trait. At least four genomic regions containing the loci involved in the resistance reaction were introgressed in the obtained lines: the regions with the $I$ gene (LG02), the Co-3/9 cluster (LG04), the $b c-3$ gene (LG06) and the Co-2 cluster (LG11). Observed phenotypic differences among fabada breeding lines could be due to two possible causes. (i) The introgressed genomic regions in line A25 could be also involved in the genetic control of morpho-agronomic traits. This hypothesis is coherent with the results of Pérez-Vega et al. (2010), who mapped the genes $I$ and $b c-3$ co-located with QTLs involved in the genetic control of days to maturity and seed length, using the RIL population Xana/Cornell 49242. (ii) Other genomic regions involved in the genetic control of some morpho-agronomic traits and derived from the donor lines were maintained in the obtained lines. Contribution of these genomic regions to the expression of these traits does not appear to be very relevant given the limited differentiation among lines. Finally, a small variation for the seed phenotype was observed in the segregating population developed in the pyramiding programs suggesting that the genetic control of seed phenotypes differ between the involved breeding lines.

The introgression of different combinations of resistance genes in fabada line A25 provides a possible resistance breaking and offers the possibility to minimize the damage caused by BCM and anthracnose disease in crops. The set of the obtained lines is a potential source of resistance for other bean breeding programs focused to protect bean genotypes against these two pathogens.

Acknowledgments This work was supported by grants RTA02052-C02-01 and RTA2005-00115-C02-01 from INIA-Ministerio de Ciencia y Tecnología, Spain. Elena Pérez-Vega was recipient of a salary fellowship from the Instituto Nacional de Investigación y Tecnología Agraria y Alimentaria (INIA, Spain). Lines A252, A321, A493 and BRB130 were originally supplied by S.P. Singh (Kimberly Research and Extension, University of Idaho). Line Sanilac BC6-Are was supplied by A de Ron (Misión Biológica de Galicia, Pontevedra, Spain).

\section{References}

Adam-Blondon AF, Sévignac M, Bannerot H, Dron M (1994) SCAR, RAPD, and RFLP markers linked to a dominant gene (Are) conferring resistance to anthracnose in common bean. Theor Appl Genet 88:865-870

Awale H, Ismail SM, Vallejo VA, Kelly JD (2008) SQ4 SCAR marker linked to the $\mathrm{Co}-2$ gene on B11 appears to be linked to the $U r-11$ gene. Annu Rep Bean Improv Coop 51:174-175

Aylesworth JW, Tu JC, Buzzell RI (1983) Sanilac BC6-Are white bean breeding line. HortScience 18:115

Balardin RS, Kelly JD (1997) Re-characterization of Colletotrichum lindemuthianum races. Annu Rep Bean Improv Coop 40:126-127

Campa A, Rodríguez-Suarez C, Pañeda A, Giraldez R, Ferreira JJ (2005) The bean anthracnose resistance gene $\mathrm{Co}-5$, is located in linkage group B7. Annu Rep Bean Improv Coop 48:68-69

Campa A, Giraldez R, Ferreira JJ (2009) Genetic dissection of the resistance to nine anthracnose races in the common bean differential cultivars MDRK and TU. Theor Appl Genet 119:1-11

Campa A, Pérez-Vega E, Ferreira JJ, Giraldez R (2010) Anthracnose resistance loci in common bean are generally organized as clusters of different race specific genes. Annu Rep Bean Improv Coop 53:142-143

Collard BCY, Mackill DJ (2008) Marker-assisted selection: an approach for precision plant breeding in the twenty-first century. Phil Trans R Soc B 363:557-572

David P, Chen NWG, Pedrosa-Harand A, Thareau V, Sévignac M, Cannon SB, Debouck D, Langin T, Geffroy V (2009) A nomadic subtelomeric disease resistance gene cluster in common bean. Plant Physiol 151:1048-1065

Drijfhout E (1978) Genetic interaction between Phaseolus vulgaris and bean common mosaic virus with implications for strain identification and breeding for resistance. Agric Res Rep 872, Agric Univ, Wageningen

Drijfhout E, Morales FL (2005) Bean common mosaic. In: Schwartz HF, Steadman JR, Hall R, Forster RL (eds) Compendium of bean diseases, 2nd edn. APS Press, St Paul, pp 60-63

Fehr WR (1987) Principles of cultivar development: theory and technique. Collier Macmillan, London

Ferreira JJ, Alvarez E, Fueyo MA, Roca A, Giraldez R (2000) Determination of the outcrossing rate of Phaseolus vulgaris $\mathrm{L}$. using seed protein markers. Euphytica 113:259-263

Ferreira JJ, Campa A, Pérez-Vega E, Giraldez R (2008) Reaction of a bean germplasm collection against five races of Colletotrichum lindemuthianum identified in northern Spain and implications for breeding. Plant Dis 92:705-708

Freyre R, Skroch PW, Geffroy V, Adam-Blondon AF, Shirmohamadali A, Johnson WC, Llaca V, Nodari RO, Pereira PA, Tsai SM, Tohme J, Dron M, Nienhuis J, Vallejos CE, Gepts P (1998) Towards an integrated linkage map of common bean. 4 . 
Development of a core linkage map and alignment of RFLP maps. Theor Appl Genet 97:847-856

Geffroy V, Sicard D, de Oliveira J, Sévignac M, Cohen S, Gepts P, Neema C, Dron M (1999) Identification of an ancestral resistance gene cluster involved in the coevolution process between Phaseolus vulgaris and its fungal pathogen Colletotrichum lindemuthianum. Mol Plant Microbe Interact 12:774-784

Geffroy V, Sévignac M, Billant P, Dron M, Langin T (2008) Resistance to Colletotrichum lindemuthianum in Phaseolus vulgaris: a case study for mapping two independent genes. Theor Appl Genet 116:407-415

Gómez P, Rodríguez-Hernández AM, Moury B, Aranda MA (2009) Genetic resistance for the sustainable control of plant virus diseases: breeding, mechanisms and durability. Eur J Plant Pathol 125:1-22

Gupta PK, Langridge P, Mir R (2010) Marker-assisted wheat breeding: present status and future possibilities. Mol Breed 26:145-161

Johnson WC, Guzman P, Mandala D, Mkandawire ABC, Temple S, Gilbertson RL, Gepts P (1997) Molecular tagging of the $b c-3$ gene for introgression into Andean common bean. Crop Sci 37:248-254

Kelly JD (1997) A review of varietal response to bean common potyvirus in Phaseolus vulgaris L. Plant Var Seeds 10:1-6

Kelly JD, Vallejo VA (2004) A comprehensive review of the major genes conditioning resistance to anthracnose in common bean. HortScience 39:1196-1207

Krüger DJ, Hoffmann GM, Hubbeling N (1977) The kappa race of Colletotrichum lindemuthianum and sources of resistance to anthracnose in Phaseolus beans. Euphytica 26:23-25

Mahuku GS, Riascos JJ (2004) Virulence and molecular diversity within Colletotrichum lindemuthianum isolates from Andean and Mesoamerican bean varieties and regions. Eur J Plant Pathol 110:253-263

Mastenbroek C (1960) A breeding program for resistance to anthracnose in dry shell haricot beans based on a new gene. Euphytica 26:23-25

Melotto M, Afanador L, Kelly JD (1996) Development of a SCAR marker linked to the $I$ gene in common bean. Genome 39:1216-1219

Méndez de Vigo B, Rodríguez-Suárez C, Pañeda A, Ferreira JJ, Giraldez R (2005) Molecular markers and allelic relationships of anthracnose resistance gene cluster B4 in common bean. Euphytica 41:237-245

Menezes JR, Dianese JC (1988) Race characterization of Brazilian isolates of Colletotrichum lindemuthianum and detection of resistance to anthracnose in Phaseolus vulgaris. Phytopathology 78:650-655

Miklas PN, Larsen RC, Riley R, Kelly JD (2000) Potential markerassisted selection for $b c-1^{2}$ resistance to bean common mosaic potyvirus in common bean. Euphytica 116:211-219

Miklas PN, Kelly JD, Beebe SE, Blair MW (2006) Common bean breeding for resistance against biotic and abiotic stresses: from classical to MAS breeding. Euphytica 147:105-131

Mukeshimana G, Pañeda A, Rodríguez-Suárez C, Ferreira JJ, Giraldez R, Kelly J (2005) Markers linked to the $b c-3$ gene conditioning resistance to bean common mosaic potyviruses in common bean. Euphytica 144:291-299

Pastor-Corrales MA (1991) Estandarización de variedades diferenciales y designación de razas de Colletotrichum lindemuthianum. Phytopathology 81:694

Pérez-Vega E, Pañeda A, Rodríguez-Suárez C, Campa A, Giraldez R, Ferreira JJ (2010) Mapping of QTLs for morpho-agronomic and seed quality traits in a RIL population of common bean (Phaseolus vulgaris L.). Theor Appl Gent 120:1367-1380

Puerta Romero J (1961) Variedades de judías cultivadas en España. Monografía No. 11, Ministerio de Agricultura, Madrid, Spain

Rodríguez-Suárez C, Méndez-Vigo B, Pañeda A, Ferreira JJ, Giraldez R (2007) A genetic linkage map of Phaseolus vulgaris L. and localization of genes for specific resistance to six races of anthracnose (Colletotrichum lindemuthianum). Theor Appl Genet 114:713-722

Rodríguez-Suárez C, Ferreira JJ, Campa A, Pañeda A, Giraldez R (2008) Molecular mapping and intra-cluster recombination between anthracnose race-specific resistance genes in the common bean differential cultivars Mexico 222 and Widusa. Theor Appl Genet 116:807-814

Schwartz HF (2005) Anthracnose. In: Schwartz HF, Steadman JR, Hall R, Forster RL (eds) Compendium of bean diseases, 2nd edn. APS Press, St Paul, pp 25-27

Singh SP (1982) A key for identification of different growth habits of Phaseolus vulgaris L. Annu Rep Bean Improv Coop 25:92-94

Singh SP, Schwartz HF (2010) Breeding common bean for resistance to diseases: a review. Crop Sci 50:2199-2223

Strausbaugh CA, Miklas PN, Singh SP, Myers JR, Forster RL (2003) Genetic characterization of differential reactions among host group common bean cultivars to NL-3K strain of bean common mosaic necrosis virus. Phytopathology 93:683-690

Voysest O (2000) Mejoramiento genético del fríjol (Phaseolus vulgaris L.). Legado de variedades de América latina 1930-1999. CIAT, Cali 